\title{
Agronomic Preliminary Performance of Two Radish Cultivars Intercropped With Coriander
}

\author{
Janiquelle da Silva Rabelo ${ }^{1}$, Marcelo de Almeida Guimarães ${ }^{1}$, Antonio Vanklane Rodrigues de Almeida ${ }^{2}$, \\ Hozano de Souza Lemos Neto ${ }^{1}$, Valsergio Barros da Silva ${ }^{2}$, Ana Régia Alves de Araújo Hendges ${ }^{1}$, \\ Caris dos Santos Viana ${ }^{1} \&$ Iana de Paula Brito Mendes ${ }^{1}$ \\ ${ }^{1}$ Departamento de Fitotecnia, Universidade Federal do Ceará, Brazil \\ ${ }^{2}$ Departamento de Engenharia agrícola, Universidade Federal do Ceará, Brazil \\ Correspondence: Janiquelle da Silva Rabelo, Departamento de Fitotecnia, Universidade Federal do Ceará, Brazil. \\ E-mail: rabelojs@hotmail.com
}

Received: August 24, 2019

doi:10.5539/jas.v11n18p173
Accepted: October 8, 2019 Online Published: November 15, 2019

URL: https://doi.org/10.5539/jas.v11n18p173

\begin{abstract}
Characterised as a traditional technique for the production of food and biomass, intercropping is a practice mainly used by small rural producers. In general, the practice has sought to maximise the use of environmental resources in an area, as well as to promote the ecological balance of different ecosystems. The aim of this study was to evaluate the performance of radish intercropped with coriander in a region of semi-arid climate. The experimental design was of randomised complete blocks, with five replications per treatment: 1) 'Cometo' radish intercropped with coriander, 2) monocropped 'Cometo' radish, 3) 'Saxa' radish intercropped with coriander, 4) monocropped 'Saxa' radish, and 5) monocropped coriander. The coriander and/or radish plants from each treatment were harvested 30 days after sowing. The following parameters were evaluated in the radish: number of leaves per plant, fresh shoot weight, shoot length, taproot length, taproot diameter, taproot weight and productivity; while in the coriander the following were evaluated: number of stems per plant, fresh shoot weight, shoot length and productivity. The Area Equivalence Efficiency (AEE) was also evaluated for the main crop. The 'Saxa' radish showed the highest productivity, both as a single crop and when intercropped (15.40 and $14.32 \mathrm{t}$ $\mathrm{ha}^{-1}$ of root, respectively). AEE values were greater than 1 in both intercrops, 2.13 and 1.70 for the intercropped 'Cometo' and 'Saxa' radish respectively, showing this cropping system to be an important way of optimising coriander cultivation in the area of study.
\end{abstract}

Keywords: Coriandrum sativum, Raphanus sativus, area equivalent efficiency, cropping systems

\section{Introduction}

Vegetables are plant species that have received special attention in recent years. This is due to the countless studies carried out that have justified their use as functional plants which also have high concentrations of nutrients essential to human life. Due to their great diversity of colour, taste and texture, vegetables have been widely used in preparing various traditional dishes in different regions of Brazil (Nascimento et al., 2017).

In the media, vegetable production has gained special prominence, as researchers and scientists from all over the world have reported that plant species which comprise this group may contribute most to a longer and healthier life (Taguchi, 2016). According to researchers, global vegetable production is approximately 7 million tons per year (Linhares et al., 2015).

In order to meet the growing demand for this group of plants, it has become increasingly necessary to adopt cropping systems that make greater productivity possible (Nascimento et al., 2017). As such, the use of intercropping techniques has been used with satisfactory results in olericulture.

Characterised as a traditional technique for the production of food and biomass in tropical regions, intercropping is a practice mainly used by small rural producers (Montezano, 2006). When carried out under an agroecological system, intercropping presents productive, nutritional, economic and environmental advantages (Mota et al., 2010). In general, the aim of this practice has been to maximise the use of environmental resources in the area, improve the control of pests, disease and weeds, reduce the use of such inputs as fertilisers and agrochemicals, and promote ecological balance (Mota et al., 2010). 
One of the vegetable crops most commonly used in intercropping is the radish (Raphanus sativus L.). Belonging to the Brassicaceae family, the radish is small in size and classified as annual. It is believed to have originated in Europe. Commercially, it is highly profitable, affording greater and faster capital turnover (Linhares et al., 2015).

In Brazil the radish is not considered a significant crop in terms of area or production, despite being an ingredient in various dishes (Linhares et al., 2015). However, the crop has established itself as an important growing option for the rural producer, since it has the characteristic of a short cycle and can be harvested 30 days after sowing, which generates quick economic return (Montezano, 2006).

Morphologically the radish plant is characterised by having a tuberous root with an epidermis of an intense red colour, being white inside. Its pungent taste is characteristic and attracts consumers around the world (Filgueira, 2008). Its short cycle, together with its hardiness, make the radish an interesting crop for use under an intercrop system (Grangeiro et al., 2008).

In addition to the radish, coriander is a widely used vegetable in Brazilian cuisine, especially in the northeast of Brazil, where it is considered a crop that affords a large turnover (Pereira et al., 2011). Its small size, together with its quick growth cycle, makes it one of the most used crops in intercrop systems.

In view of the above, the aim was to evaluate the performance of two radish cultivars intercropped with coriander leaf under the soil and climate conditions of the town of Pentecoste, located in the semi-arid region of the State of Ceará, where vegetable production is still limited and not very significant.

\section{Method}

The experiment was carried out in the field, from February to April 2016, in a region destined for activities related to family and organic farming. The area is located in the Curu Valley, in the town of Pentecoste, in the State of Ceará.

The experimental design was of randomised blocs, with five replications per treatment. The treatments used were 1) 'Cometo' Radish (Raphanus sativus) intercropped with coriander (Coriandrum sativum), 2) monocropped 'Cometo' radish, 3) 'Saxa' radish intercropped with coriander, 4) monocropped 'Saxa' radish, and 5) monocropped coriander.

The predominant soil in the cropping area had a sandy-loam texture. The characteristics of the soil indicated: $\mathrm{pH}$ $=7.0, \mathrm{P}=66.51 \mathrm{mg} \mathrm{dm}{ }^{-3}, \mathrm{~K}^{+}=160.00 \mathrm{mg} \mathrm{dm}{ }^{-3}, \mathrm{Ca}^{2+}=7.3 \mathrm{cmolc} \mathrm{dm}^{-3}, \mathrm{Mg}^{2+}=3.80 \mathrm{cmolc} \mathrm{dm}^{-3}, \mathrm{Al}^{3+}=0.00$ cmolc. $\mathrm{dm}^{-3}, \mathrm{H}+\mathrm{Al}=0.00 \mathrm{cmolc} \mathrm{dm}{ }^{-3}, \mathrm{SB}=12.03 \mathrm{cmolc} \mathrm{dm}^{-3}, \mathrm{CEC}(\mathrm{t})=12.03 \mathrm{cmolc} \mathrm{dm}^{-3}, \mathrm{CTC}(\mathrm{T})=\mathrm{H}+\mathrm{Al}$ $=19.64 \mathrm{cmolc} \mathrm{dm}^{-3}, \mathrm{~V}=100.00 \%$ and $\mathrm{m}=0.00 \%$. ISNa $=4.34 \%, \mathrm{OM}=2.07$ dag Kg${ }^{-1}, \mathrm{P}-\mathrm{rem}=45.7 \mathrm{mg} \mathrm{L}^{-1}, \mathrm{Zn}$ $=4.4 \mathrm{mg} \mathrm{dm}^{-3}, \mathrm{Fe}=130.9 \mathrm{mg} \mathrm{dm}^{-3}, \mathrm{Mn}=95.8 \mathrm{mg} \mathrm{dm}^{-3}, \mathrm{Cu}=1.4 \mathrm{mg} \mathrm{dm}^{-3}$ and $\mathrm{B}=0.5 \mathrm{mg} \mathrm{dm}^{-3}$.

Weeding, soil turning to a depth of $0.30 \mathrm{~m}$ and the incorporation of $200 \mathrm{~L}$ of organic compost were carried out to prepare an area of $10 \mathrm{~m}^{2}$. This was followed by the levelling and declumping of the soil to facilitate sowing and crop development.

Each of these operations was carried out manually using a hoe, with the aim of creating the physical and chemical conditions of the soil necessary for the tuberous roots of the radish to develop well.

The spacing used for the radish was $0.1 \mathrm{~m}$ between plants and $0.2 \mathrm{~m}$ between rows. The rows of coriander were spaced $0.2 \mathrm{~m}$ from the rows of radish and, when grown as a monocrop, from the other rows of coriander.

Each plot had a total area of $2 \mathrm{~m}^{2}$, with only the 20 central radish plants and the two central rows of coriander in each treatment considered for each plot.

Cultivation of the radish and coriander was by direct sowing. For the radish, two seeds were sown per hole; for the coriander, $4 \mathrm{~g}$ of seed were evenly distributed per linear metre of crop row. The cultivars of radish used were Cometo and Saxa, while 'Verdão' was used for the coriander.

Hand weeding was carried out every week to control invasive plants. Fifteen days after sowing, neem extract was applied to reduce the level of attack by pests.

To prepare the extract, $100 \mathrm{~g}$ of immature neem fruit were harvested at the time of preparation. The fruit was shredded in a blender with $1 \mathrm{~L}$ of water to obtain the $10 \%$ extract $(\mathrm{w} / \mathrm{v})$. The extract was applied at a dose of $0.5 \%(\mathrm{w} / \mathrm{v})$.

Fifteen days after sowing the crops in the field, cover fertilisation was carried out, with $40 \mathrm{~L}$ of organic compost placed in each plot $\left(2 \mathrm{~m}^{20}\right)$.

The radish plants in each treatment were harvested 30 days after sowing and the following parameters were obtained: 1) number of leaves per plant (NL), 2) shoot fresh weight (SFW, g plant $\left.{ }^{-1}\right), 3$ ) shoot length $(\mathrm{cm})$ with 
the help of a tape measure; 4) taproot length (measured with a digital calliper (TL, mm), 5) taproot diameter (TD, $\mathrm{mm})$, 6) taproot fresh weight (TFW, g plant $\left.{ }^{-1}\right)$, and 7) Productivity, with raddish root yield and with coriander above-ground plant material $\left(\mathrm{P}, \mathrm{t} \mathrm{ha}^{-1}\right)$.

The coriander plants were evaluated for 1) number of stems per plant (NS), 2) shoot fresh weight (SFW, g plant $\left.^{-1}\right)$, 3) shoot length $(\mathrm{cm})$, and 4) productivity $\left(\mathrm{P}, \mathrm{t} \mathrm{ha}^{-1}\right)$.

In addition to the agronomic aspects, the Area Equivalence Efficiency was also evaluated: AEE $=[$ (productivity of the intercropped radish/productivity of the monocropped radish) + (productivity of the intercropped coriander/productivity of the monocropped coriander)], as per Montezano and Peil (2006).

The data were submitted to analysis of variance using the Sisvar software (Ferreira, 2011), and when a difference was found between treatments, they were compared by the Scott-Knott cluster test at a significance level of 5\%.

\section{Results}

The monocrop and intercrop systems did not influence the characteristics under evaluation in either of the two radish cultivars being studied (Table 1). However, a difference was found for each characteristic when the two cultivars were compared with each other, irrespective of the cropping system (Table 1). 'Saxa' presented the highest values for each characteristic under evaluation compared to 'Cometo'.

Table 1. Number of leaves (NL), shoot length (SL), shoot fresh weight (SFW), taproot length (TL), taproot diameter (TD) and taproot fresh weight (TFW) in two radish cultivars grown as monocrops or intercropped with coriander, 30 days after sowing

\begin{tabular}{lllllll}
\hline Treatment & NL & SL $(\mathrm{cm})$ & SFW $\left(\mathrm{g} \mathrm{plant}^{-1}\right)$ & TL $(\mathrm{mm})$ & TD $(\mathrm{mm})$ & TFW $\left(\mathrm{g} \mathrm{plant}^{-1}\right)$ \\
\hline Intercropped 'Cometo' & $7.05 \mathrm{~b}$ & $18.28 \mathrm{~b}$ & $20.00 \mathrm{~b}$ & $40.82 \mathrm{~b}$ & $32.77 \mathrm{~b}$ & $25.7 \mathrm{~b}$ \\
Intercropped 'Saxa' & $7.68 \mathrm{a}$ & $22.54 \mathrm{a}$ & $28.00 \mathrm{a}$ & $51.23 \mathrm{a}$ & $34.16 \mathrm{a}$ & $28.6 \mathrm{a}$ \\
Monocropped 'Cometo' & $7.14 \mathrm{~b}$ & $19.58 \mathrm{~b}$ & $18.00 \mathrm{~b}$ & $37.37 \mathrm{~b}$ & $32.94 \mathrm{~b}$ & $27.0 \mathrm{~b}$ \\
Monocropped 'Saxa' & $7.57 \mathrm{a}$ & $23.42 \mathrm{a}$ & $30.00 \mathrm{a}$ & $49.37 \mathrm{a}$ & $34.58 \mathrm{a}$ & $30.0 \mathrm{a}$ \\
\hline CV (\%) & 5.08 & 13.88 & 27.69 & 17.40 & 9.10 & 8.10 \\
\hline
\end{tabular}

Note. Mean values followed by the same letter in a column do not differ at a significance level of $5 \%$ by the Scott-Knott cluster test.

The difference seen between the two radish cultivars under evaluation showed better adaptation by 'Saxa' to the soil and climate conditions of Pentecoste when compared to 'Cometo', since even under the monocrop system, the former presented more significant production values.

The greater number of leaves emitted by 'Saxa' in relation to 'Comet', as well as the higher values seen for shoot length and fresh weight, may have decisively interfered in the higher values found for taproot characteristics and productivity, which, irrespective of the cropping system, were always greater than seen for 'Cometo'.

For the coriander, both the monocrop and the intercrop with the 'Cometo' radish showed the greatest values for shoot length, number of stems and plant fresh weight, differing from the coriander intercropped with 'Saxa' (Table 2).

Table 2. Number of stems per linear metre (NS), shoot length (SL) and shoot fresh weight per linear metre (SFW) in coriander grown between the rows of two radish cultivars (Cometo and Saxa), 30 days after sowing

\begin{tabular}{llll}
\hline Treatment & NS & SL (cm) & SFW (Kg) \\
\hline Coriander intercropped with the 'Cometo' radish & $266.10 \mathrm{a}$ & $35.70 \mathrm{a}$ & $0.172 \mathrm{a}$ \\
Coriander intercropped with the 'Saxa' radish & $117.20 \mathrm{~b}$ & $30.40 \mathrm{~b}$ & $0.111 \mathrm{~b}$ \\
Monocrop of coentro & $314.70 \mathrm{a}$ & $33.60 \mathrm{a}$ & $0.146 \mathrm{a}$ \\
\hline CV $(\%)$ & 17.62 & 6.51 & 14.58
\end{tabular}

Note. Mean values followed by the same letters in a column do not differ at a significance level of $5 \%$ by the Scott-Knott cluster test. 
For productivity in the radish, it can be seen in Figure 1 that 'Saxa', under both the monocrop and intercrop systems (15.40 and $14.32 \mathrm{t} \mathrm{ha}^{-1}$ respectively), produced approximately $15 \%$ more than 'Cometo' (13.50 and $12.86 \mathrm{t} \mathrm{ha}^{-1}$ respectively) grown under the same cropping systems (Figure 1).

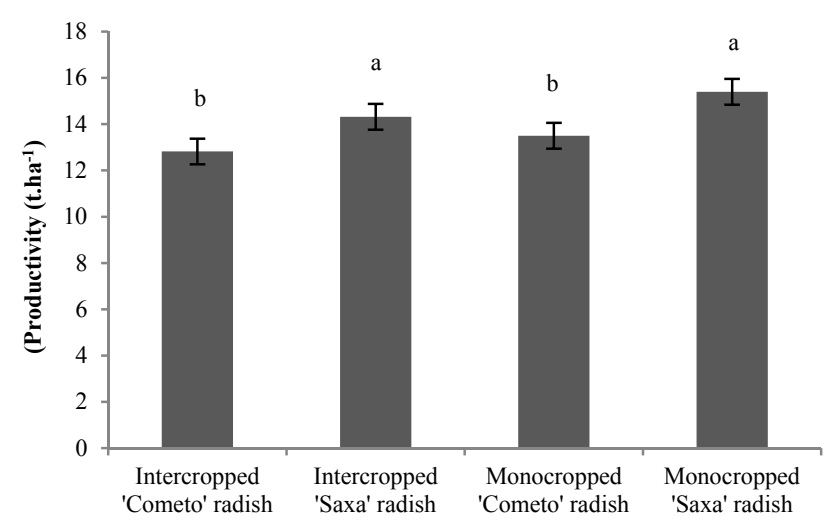

Figure 1. Productivity in the radish, intercropped with coriander and as a monocrop

The greatest values seen for productivity in the coriander (Figure 2) were in the intercrop with the 'Cometo' radish and in the monocrop (8.64 and $7.33 \mathrm{t} \mathrm{ha}^{-1}$ respectively).

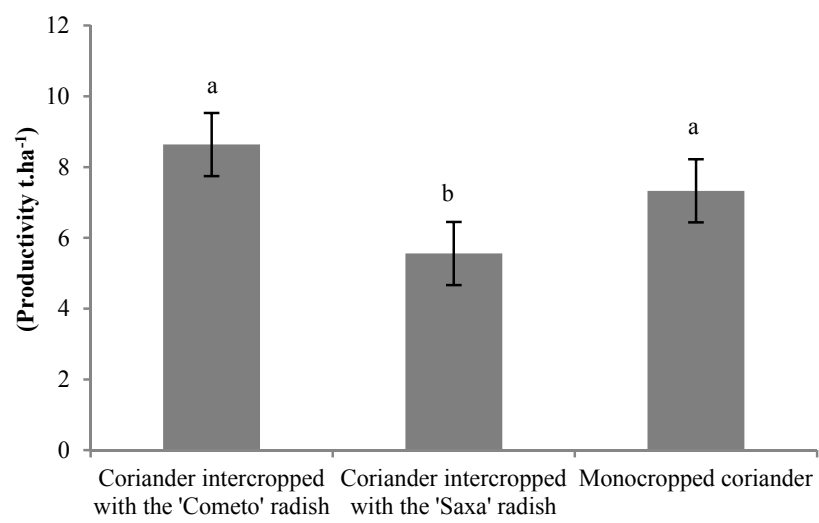

Figure 2. Productivity in coriander, intercropped with two cultivars of radish and as a monocrop

Regarding the efficiency of intercropping in relation to the monocrops, it can be seen from the Area Equivalence Efficiency (AEE) that intercropping gave values greater than 1, of 2.13 and 1.70 for the 'Cometo' and 'Saxa' radish respectively, and that in general, the crops used in the intercrop showed a potential for making use of productive space when grown concurrently. According to the results, an increase of $113 \%$ in cultivated area would be required for 'Cometo' to produce, under the monocrop system, the same weight of taproots produced in the intercrop with coriander, while for 'saxa', the necessary increase in area would be $70 \%$.

\section{Discussion}

According to Taiz and Zeiger (2013), the leaves are the organs responsible for intercepting and converting light energy into photo-assimilates for the plant. The greater number of leaves emitted by 'Saxa' may have given it a larger leaf area, i.e. the plants of this cultivar possibly intercepted a greater amount of solar energy and were thereby able to carry out more photosynthesis. This increase in the production of photoassimilates, which were mainly directed to the strongest sinks, in the case of this species, to the taproots (Gonzalez-Sanpedro et al., 2008).

Other researchers, working with radish intercropped either with coriander or with other crops in locations with different climate conditions than those seen in this study, have had differing results. Granjeiros et al. (2008), evaluating productivity in radish intercropped with coriander, found no difference for systems set up at different 
times. On the other hand, Cecílio Filho and May (2002) found greater productivity in radish under an intercrop system compared to the monocrop. Rezende et al. (2014), working with radish intercropped with lettuce, achieved greater productivity in the radish under the intercrop system, approximately $17 \mathrm{tha}^{-1}$, while under the monocrop system, productivity was approximately $8 \mathrm{tha}^{-1}$.

As the crop is suitable for production in regions of mild climate (Filgueira, 2008), both radish cultivars showed good productivity, even under the semi-arid soil and climate conditions of Pentecoste, Ceará; this was because they were close to the mean range for productivity of 15 to 30 tons of roots per hectare, reported by Guimarães and Feitosa (2014) as the mean recurrent range for productivity in commercial crops.

From the success obtained with intercropping, irrespective of the radish cultivar associated with the coriander, one inference is the possible promotion of greater ecological balance, since this cropping system aims to maximise the use of environmental resources in the area and reduce the incidence of pests, diseases and weeds, avoiding the use of fertilisers and pesticides (Mota et al., 2010). Another important point, according to researchers and also seen in this study, is the efficiency of the intercrop, which depends directly on the system and the crops involved, since a so-called complementarity occurred between the intercropped species, showing it to be a more advantageous practice than the monocrop of each of the species under evaluation (Cecílio and Taveira, 2001).

\section{Conclusion}

Based on one year's data, it is concluded that intercropping radish with coriander can be recommended as a cropping system for the soil and climate conditions of the region under study, with the Saxa cultivar being the most suitable for production under such conditions, regardless of the type of cropping system adopted, whether monocrop or intercrop.

\section{References}

Cecílio Filho, A. B., \& May, A. (2002). Produtividade das culturas de alface e rabanete em função da época de estabelecimento do consórcio. Horticultura Brasileira, 20(3), 501-504. https://doi.org/10.1590/S010205362002000300021

Cecílio Filho, A. B., \& Taveira, M. C. G. S. (2001). Produtividade da cultura da beterraba em função da época de estabelecimento do consórcio com rúcula. Horticultura Brasileira, 19(2). https://doi.org/10.1590/ S0102-05362007000400016

Ferreira, D. F. (2011). Sisvar-Sistemas de análises estatísticas (Versão 5.3). Lavras: Departamento de Ciências Exatas, UFLA.

Filgueira, F. A. R. (2008). Novo Manual de Olericultura: Agrotecnologia moderna na produção e comercialização de hortaliças (2nd ed., p. 402). Viçosa: UFV.

Gonzalez-Sanpedro, M. C., Toan, T. Le, Moreno, J., Kergoat, L., \& Rubio, E. (2008). Seasonal variations of leaf area index of agricultural fields retrieved from Landsat data. Remote Sensing of Environment, 112, 810-824. https://doi.org/10.1016/j.rse.2007.06.018

Grangeiro, L. C., Negreiros, M. Z., Santos, A. P., Costa, L. M., Silva, A. R. C., \& Lucena, R. R. M. (2008). Crescimento e produtividade de coentro e rabanete em função da época de estabelecimento do consórcio. Revista Ciência Agrotecnologia, 32(1), 55-60. https://doi.org/10.1590/S1413-70542008000100008

Guimarães, M. A., \& Feitosa, F. C. (2014). Rabanete: Condições ideais para o cultivo (Vol. VIII, No. 106). Campo \& Negócio HF, Uberlândia, MG.

Linhares, P. C. F., Oliveira, J. D., Almeida, A. M. B., Neves, A .P. M., Cunha, L. M. M., Coelho, D. C., \& Silva, F. M. (2015). Eficiência econômica da aplicação do esterco bovino na cultura do rabanete. INTESA, 9(1), 59-63. Retrieved from https://www.gvaa.com.br/revista/index.php/INTESA/article/view/3224

Montezano, E. M., \& Peil, R. M. N. (2006). Sistema de consórcio na produção de hortaliças. Revista Brasileira de Agrociencia, 12, 129-132. https://doi.org/10.18539/cast.v12i2.4502

Mota, J. H., Vieira, M. C., \& Cardoso, C. A. L. (2010). Alface e jateikaá em cultivo solteiro e consorciado: Produção e atividade antioxidante. Ciência e Agrotecnologia, 3, 551-557. https://doi.org/10.1590/S141370542010000300004

Nascimento, M. V., Silva junior, R. L., Fernandes, L. R., Xavier, R. C., Benett, K. S. S., Seleguini, A., \& Benett, C. G. S. (2017). Manejo da adubação nitrogenada nas culturas de alface, repolho e salsa. Revista de Agricultura Neotropical, 4(1), 65-71. https://doi.org/10.32404/rean.v4i1.1099 
Pereira, M. F. S., Torres, S. B., Linhares, P. C. F., Paiva, A. C. C., Paz, A. E. S., \& Dantas, A. H. (2011). Qualidade fisiológica de sementes de coentro [Coriandrum sativum (L.)]. Revista Brasileira Plantas Medicinais, 13, 518-522. https://doi.org/10.1590/S1516-05722011000500002

Rezende, E. G., Gomes, M. S., Agostinho, P. R., Xavier, R. M., \& Silva, R. F. (2014). Produção orgânica de alface e rabanete em cultivo solteiro e consorciado. Revista Verde, 9(2), 208-212.

Taguchi, V. (2016). Em seis meses, Espanha exportou quase $7 \mathrm{mil} \mathrm{t}$ de frutas e hortaliças. Hortifruti. Revista Globo Rural. Retrieved from http://revistagloborural.globo.com/Noticias/Agricultura/Hortifruti/noticia/ 2016/10

Taiz, L., \& Zeiger, E. (2013). Fisiologia Vegetal (5th ed., p. 918). Porto Alegre: Artmed.

Vandermeer, J. (1981). The interference production principle: An ecological theory for agriculture. Bioscience, 31, 361-364. https://doi.org/10.2307/1308400

Zanol, S. V., Farias, R. M., Martins, C. R., Rossorolla, M. D., \& Pivoto, H. C. (2007). Cultivo de hortaliças companheiras em sistema agroecológico, período primavera-verão na situação de Uruguaiana-RS. Revista Brasileira de Agroecologia, 2(1), 1549-1552.

\section{Copyrights}

Copyright for this article is retained by the author(s), with first publication rights granted to the journal.

This is an open-access article distributed under the terms and conditions of the Creative Commons Attribution license (http://creativecommons.org/licenses/by/4.0/). 